\title{
Impact Force and Rope Tension Affect Likelihood of Cutting a Climbing Rope with a Handsaw
}

\author{
Brian Kane, Mollie Freilicher, Mac Cloyes, and H. Dennis Ryan
}

\begin{abstract}
A previous study has demonstrated the ease with which a climber could cut his or her rope using a handsaw (Kane et al. 2009). In a previously published effort, however, the authors did not examine the effect of two variables that presumably influence the ease with which a rope can be cut: rope tension and impact force of the blade. In the current study, two types of rope are cut using one type of blade, with varied rope tension (seven levels) and impact force (four levels) of the pendulum-mounted blade on the rope. Increases in impact force and rope tension increased the ease of cutting both ropes tested, but impact force was the dominant effect. At the greatest impact force, which was similar to the impact force a climber could exert using two hands on a handsaw, all but one rope was completely severed. The results are discussed in the context of climber safety.

Key Words. Handsaw; Rope.
\end{abstract}

A previous paper documented the ease with which a climber could cut through his or her rope with a handsaw (Kane et al. 2009). In the interest of quickly publishing those results to increase awareness of the inherent danger, the effect of two presumably important variablesrope tension and impact force (or velocity) of the blade-were not investigated. The impetus for this line of investigation was an accident, where a climber cut himself out of a tree using his handsaw, resulting in a fall that broke his neck (Georgia Arborist Association 2009).

There are many ways a climber's handsaw (or pole saw) might contact the lanyard or climbing line. The impact force of the blade on the rope and rope tension can both vary dramatically. For example, climbing on a static system, such as when ascending the tree using the single rope technique, a climber's full weight is on the climbing line. In contrast, when using a dynamic climbing system, which is typically how climbers work once secured in the tree, a climber's weight is supported roughly equally by the two legs of rope attached to his or her saddle. Dynamic loading of the rope, such as when a climber swings (intentionally or by accident), will increase rope tension. In other cases, when a climber is standing on a branch or on spikes, secured to the trunk with a lanyard, the tension in the lanyard will be less than the climber's weight.

With respect to the impact force of a saw on the rope, a climber could exert full force with two hands on the saw and finish cutting a branch sooner than expected, hitting the rope. In contrast, the saw might unintentionally contact the rope as the climber puts the saw back in its scabbard. The objective of this study was to quantify the effects of rope tension and impact force of the blade on the likelihood of cutting one's climbing rope with a handsaw.

\section{METHODS AND MATERIALS}

Ropes and blades were tested as previously described (Kane et al. 2009), which included hanging a $2.13 \mathrm{~m}$ section of rope from a beam and swinging a pendulum-mounted saw blade (Figure 1) into the rope under tension. For the current investigation, one type of blade was used (alternating between five individuals), Silky Zubat, and two types of rope [Poison Ivy (24-strand construction, $11.7 \mathrm{~mm}$ nominal diameter) and XTC (16-strand construction, $12.7 \mathrm{~mm}$ nominal diameter), both manufactured by Yale Cordage, Saco, ME]. The authors chose Zubat because the handsaw completely severed each previously tested rope (Kane et al. 2009). Ropes were chosen mostly out of convenience, as unused rope of both types remained after the previous investigation (Kane et al. 2009). The choice also reflected a desire to test ropes of constructions and diameters commonly used by climbers.

The authors tested ropes in a randomized complete block design, blocking rope tension $(111,156,200,267,311,356,400 \mathrm{~N})$ within each height of swing of the pendulum (quarter, half, threequarters, and full, which corresponded to impact forces of 143, $267,509,731 \mathrm{~N}$ ), and repeating each rope by swing by tension test three or five times. To save rope, if a particular rope was cut completely through on the first three tests of any swing by tension combination, the last two tests were not conducted. Measurements of rope diameter were taken under tension before and after testing, calculating the percent difference as the response variable (percent cut). The impact force measured when the second and third authors pulled on a handsaw handle attached to a load cell $(\mathrm{n}=20)$ ranged from $267 \mathrm{~N}$ (one-handed) to $738 \mathrm{~N}$ (two-handed).

The authors used a three-way analysis of variance (ANOVA) to investigate the effects of the type of rope, rope tension, impact force, and their interactions, on percent cut. To separate significant $(\mathrm{p}<0.01)$ means, orthogonal polynomial comparisons were used. The 'contrast' statement in the GLM procedure in SAS (ver. 9.1, Cary, NC) was used within significant main effects. For significant interactions, the 'slice' statement in the GLM procedure was used to investigate differences between 

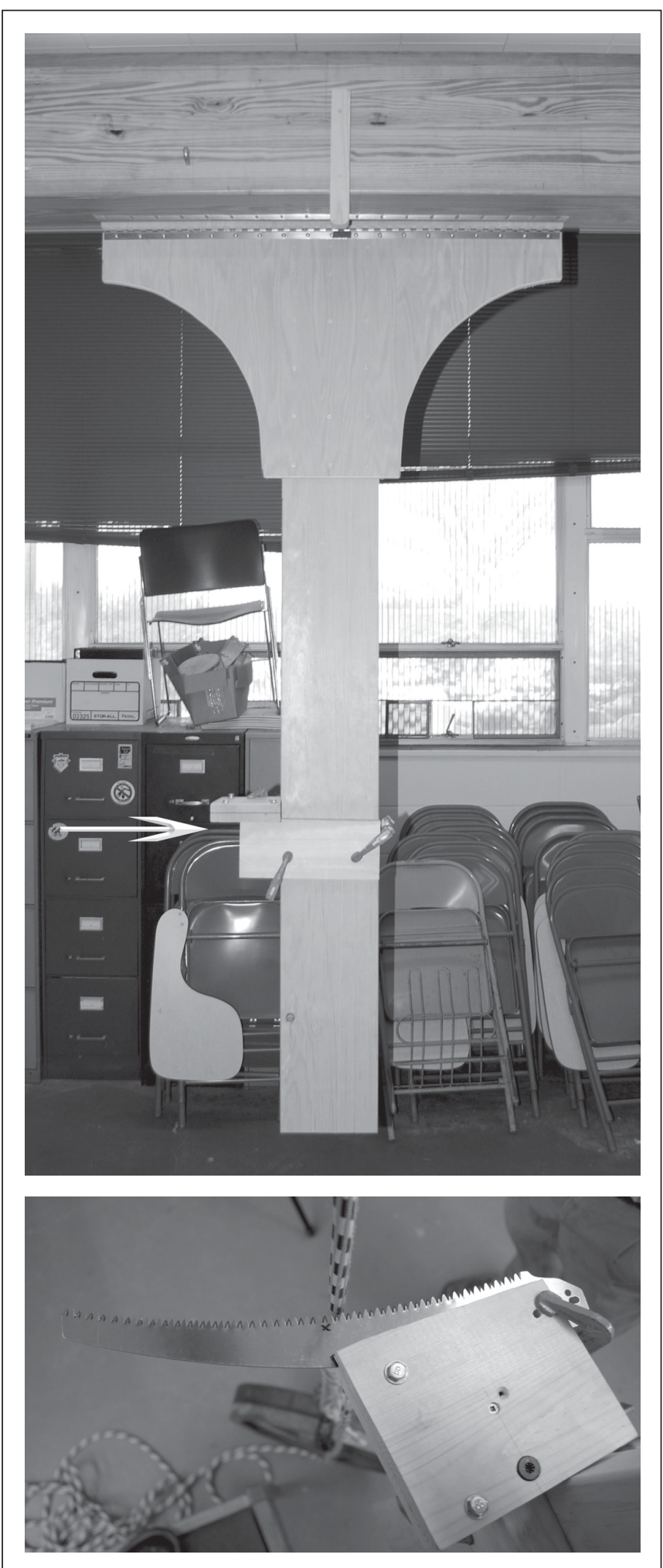

Figure 1. Experimental setup: (top) pendulum attached to beam, the arrow points to the jig that held blades; and (bottom) a closeup view of the jig, where the " $X$ " marks the tooth that first made contact with the rope.

levels of the subordinate main effect (as determined by F-value) within each level of the dominant main effect. Then the "con- trast' statement was used to separate means within each significant level of the dominant effect. Contrasts were developed for linear through the appropriate polynomial, depending on the degrees of freedom of the effect. The contrast with the greatest F-value was used to describe the relationship. For example, since there were three degrees of freedom for the effect of swing, the authors developed linear, quadratic, and cubic polynomials to separate means. Simple regression was used to quantify the relationship between percent cut and impact force of the blade.

\section{RESULTS}

Zubat blades cut similarly $(\mathrm{p}=0.0690)$ through Poison Ivy (least squares mean $=69 \%$ ) and XTC (least squares mean $=$ $71 \%$ ), so pooled results are presented for the remainder of the paper. Swing was the dominant effect determining percent cut; in the ANOVA, its F-value (705) was nearly six times greater than the F-value for rope tension (120). Percent cut increased quadratically with increasing swing height (Figure 2). The F-value for the quadratic contrast of swing heights $(1,982)$ was 27 times greater than the F-value for the linear contrast (72.5), and 48 times greater than the F-value for the cubic contrast (41.6) even though all three were significant $(\mathrm{p}<0.0001)$. Full swings cut completely through 53 of 54 ropes tested; one rope was cut through $89 \%$, at the smallest rope tension $(143 \mathrm{~N})$. In contrast, only two ropes were completely severed during quarter swings of the pendulum, both occurred when ropes were under maximum tension $(400 \mathrm{~N})$. Excepting full swings [within which the effect of rope tension was not significant $(\mathrm{p}=1.000)]$, within each swing height, percent cut increased quadratically with increased rope tension (Figure 2). The effect of rope tension was most pronounced at quarter swings, within which the quadratic relationship among rope tensions was positive. Within half and three-quarters swings, the quadratic relationship among rope tensions was negative, which reflected the complete severing of all ropes when rope tension exceeded $311 \mathrm{~N}$ and $156 \mathrm{~N}$ for one-half and three-quarters swings, respectively (Figure 2).

\section{DISCUSSION}

In light of the many ways a saw blade and rope may come into contact, the most important finding is that across a realistic range of impact forces and rope tensions, it is easy to cut through one's climbing rope with a handsaw, supporting previous research (Kane et al. 2009). As previously speculated (Kane et al. 2009), impact force and rope tension both affected the likelihood of a climber cutting through his or her rope, although impact force was clearly the dominant effect. Part of its dominance may be due to the wider range of impact forces measured, which was 1.4 times greater than the range of tested rope tensions.

At full swings equivalent to the impact force a climber can exert with two hands on the handsaw, a climber can easily cut his or her rope, even if it is under little tension. Standing on a branch, but otherwise fully supported by his lanyard, a $75 \mathrm{~kg}$ climber exerted $222 \mathrm{~N}$ of tension in the lanyard (pers. obs.). It is unclear whether the maximum impact force would mimic the force a climber exerted as he or she actually cut through a branch, but many climbers have prematurely severed a branch while still exerting considerable force on the saw. Perhaps the greater risk would occur when a climber is making a cut but unaware the rope is in the path of the saw blade. Another dangerous scenario 


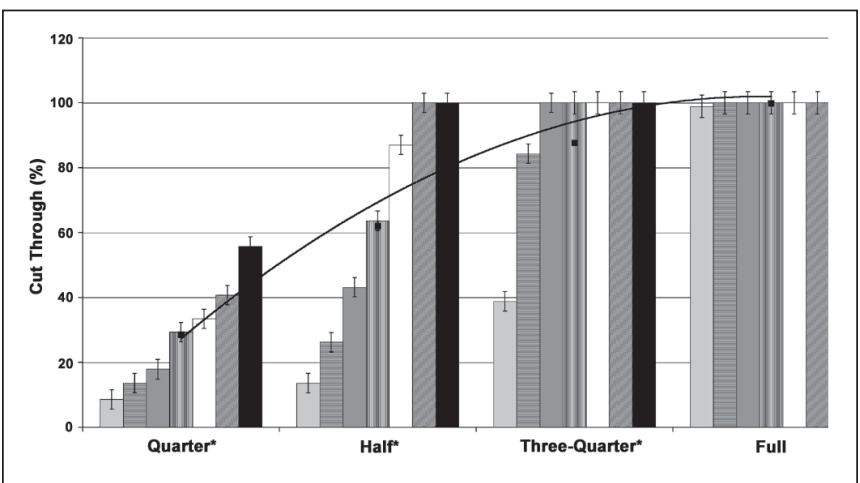

Figure 2. Least squares means (whiskers represent SE) of percent cut for each rope tension (from left to right, columns correspond to $111,156,200,267,311,356$, and $400 \mathrm{~N})$ within each swing. Swings followed by an asterisk (*) indicate percent cut varied among rope tensions within that swing by orthogonal polynomial comparison ( $p<0.0001)$. Within Quarter, Half, and Three-Quarters swings, the quadratic comparison among rope tensions had the greatest F-value. The overall least squares mean of percent cut (E) was also significantly different $(p<0.0001)$ among swings $(S)$; the best-fit line $\left(r^{2}=0.57\right)$ was quadratic: percent cut $=-0.0002 S^{2}$ $+0.3101 S-8.9563$.

entails a pole saw falling from a branch and contacting the climbing rope; this could generate large impact forces, depending on the mass of the pole saw and how far it fell. Impact force of the blade on the rope is considered in each of these examples. Impact cutting of a rope under tension likely does more damage to the rope than either slowly cutting the rope (under the same tension) or cutting the rope and then applying static or dynamic tension, as observed on nylon kernmantle ropes (Contri and Secchi 2002). Regardless of the circumstances when the rope and blade come into contact, it is important to remember that for the amount of damaged fibers in the rope, cutting reduces rope strength more than fibers lost through normal abrasion (Flory 2008).

The negative quadratic best-fit lines relating percent cut to (a) the overall effect of increasing impact force, and (b) the effect of increasing rope tension within half and three-quarter swings, indicate impact forces greater than $267 \mathrm{~N}$ are very likely to completely sever the rope, regardless of rope tension. In contrast, the positive quadratic relationship between percent cut and increasing rope tension within quarter swings demonstrates that, at small impact forces, increasing rope tension increases the likelihood of completely severing one's climbing rope. Curvilinear trends were expected because the mechanical behavior of rope is typically nonlinear (McLaren 2006). It is speculated that there is a rope tension, even at small impact forces, at which all ropes would be completely severed. When an $81 \mathrm{~kg}$ climber is tied-in to a tree with the conventional doubled rope technique, there is approximately 400 $\mathrm{N}$ of tension throughout the rope. Ascending into the tree using the single rope technique (SRT), however, means the climber's full weight $(800 \mathrm{~N})$ tensions the rope. Thus, doubling the rope tension may more than double the risk of completely severing one's climbing rope at small impact forces. Climbers who use SRT for ascension should be extremely cautious when using their handsaw during an ascent, for example to remove a sucker blocking their path.

The lack of difference between Poison Ivy and XTC, which have different diameters and constructions, supports previous findings where these ropes did not differ when cut by several dif- ferent blades (Kane et al. 2009). It is unclear why this occurred, but it is speculated that the different constructions impart different degrees of friction between fibers and yarns within each strand. In their numerical simulation of cutting kernmantle ropes, Contri and Secchi (2002) predicted that as friction coefficients increased, transverse displacement of the rope into the blade would decrease. They also observed significant transverse displacement of ropes in the direction of the blade during experimental tests in which the rope was transversely unconstrained, which caused a deeper cut (Contri and Secchi 2002). Since their test method was similar to the method used in the current study, greater friction among strands in the sheath of Poison Ivy may have reduced its transverse displacement into the blade, reducing the depth of cut.

The authors do not intend to understate the danger of cutting oneself out of a tree using a handsaw. However, assuming a roughly one-to-one relationship between the degree to which a rope is cut and its subsequent loss in strength (Kane et al. 2009), it is helpful to remember a $50 \%$ cut would reduce the average tensile strength of Poison Ivy and XTC to roughly $14 \mathrm{kN}$. This value still exceeds the $12 \mathrm{kN}$ impact force at which the human body would presumably suffer life-threatening damage (Anonymous 1953), and which is used as the maximum impact force in standard drop tests (Anonymous 2004). Thus, even relatively severe cuts do not always and immediately imply rope failure and climber injury. Future tests should consider used ropes, since normal wear and tear gradually reduces the number of rope fibers and weaken the rope.

In the near term, it is impractical to cost-effectively manufacture cut-resistant rope that also maintains the current balance of strength, abrasion resistance, and energy absorption. A simpler approach to avoiding accidents involving climbers cutting their ropes is to raise awareness of the possibility of such accidents, and training climbers to consider where their rope is in relation to where they are cutting.

Acknowledgments. We thank Bartlett Tree Experts for funding this project, Yale Cordage for donating rope, and Wesley Autio and Dan Pepin (University of Massachusetts) for statistical advice and designing and building the pendulum, respectively.

\section{LITERATURE CITED}

Anonymous. 1953. Force distribution in a parachute harness (interim report). Equipment Laboratory, Directorate of Laboratories, WrightPatterson Air Force Base, Ohio. U.S. Air Force Technical Memorandum Report WCLE-53-292.

Anonymous. 2004. Mountaineering equipment-dynamic mountaineering ropes - safety requirements and test methods. European Committee for Standardization CEN-EN 892.

Contri, L., and S. Secchi. 2002. Snapping of ropes under stress. In: Nylon and ropes for mountaineering and caving, Italian Alpine Club Technical Committee, Turin, Italy.

Flory, J. 2008. Assessing strength loss of abraded and damaged fiber rope, pp. 227-234. In: Oil Companies International Marine Forum. Mooring Equipment Guidelines 3rd Ed. Witherby Seamanship International, London, England.

Georgia Arborist Association. 2009. Industry Incidents in Georgia. $<$ http://georgiaarborist.camp8.org/Default.aspx?pageId=238936>.

Kane, B., M. Cloyes, M. Freilicher, and H.D.P. Ryan. 2009. Damage Inflicted on Climbing Ropes by Handsaws. Arboriculture \& Urban Forestry 35(6):305-310.

McLaren, A.J. 2006. Design and performance of ropes for climbing and sailing. J. Materials: Design \& Applications 220:1-12. 
Brian Kane (corresponding author)

Dept. of Natural Resources Conservation Holdsworth Hall

University of Massachusetts

Amherst, MA 01003, U.S.

bkane@nrc.umass.edu

Mollie Freilicher

Dept. of Natural Resources Conservation

Holdsworth Hall

University of Massachusetts

Amherst, MA 01003, U.S.

Mac Cloyes

Dept. of Natural Resources Conservation

Holdsworth Hall

University of Massachusetts

Amherst, MA 01003, U.S.

H. Dennis Ryan

Dept. of Natural Resources Conservation

Holdsworth Hall

University of Massachusetts

Amherst, MA 01003, U.S.
Résumé. Une étude précédente a démontré la facilité avec laquelle un grimpeur peut couper sa corde au moyen d'une scie à main (Kane et al. 2009). Cependant, lors de la publication précédente, les auteurs n'avaient pas examiné l'effet de deux variables qui pouvaient possiblement influencer la facilité avec laquelle une corde pouvait être coupée: la tension de la corde et l'impact de la force de la lame. Dans la présente étude, deux types de cordes ont été coupées au moyen d'un seul type de lame, le tout avec sept degrés différents de tension sur la corde et quatre degrés différents de force d'impact appliqués par la lame montée en pendule. L'accroissement de la force d'impact et de la tension sur la corde augmentait la facilité avec laquelle les deux types de cordes étaient coupées, mais la force d'impact était la variable qui avait l'effet le plus dominant. Lors de la force d'impact la plus élevée, qui était similaire à celle qu'un grimpeur pouvait exercer sur une scie avec ses deux mains, toutes les cordes sauf une ont été entièrement brisées. Les résultats sont discutés dans le contexte de la sécurité d'un grimpeur.

Zusammenfassung. In einer früheren Studie konnte demonstiert werden, mit welcher Leichtigkeit ein Kletterer sein/ihr Seil mit der Handsäge kappen kann (Kane et al. 2009). In dem zuvor veröffentlichen Versuch haben die Autoren jedoch nicht den Einfluss von zwei Variablen untersucht, die vermutlich einen Einfluss auf die Kappung haben können: die Seilspannung und die Kraft des Sägeblatts. In dieser Studie werden zwei verschieden Seile mit einem Typ Sägeblatt gekappt, mit verschiedenen Seilspannungen (sieben Stufen) und 4 Kraftstufen bei dem Sägeblattpendel. Zunehmende Kraft und Spannung erhöhten die Leichtigkeit des Kappens bei beiden Seilen, aber die aufgewendete Kraft hatte den größten Einfluss. Bei der größten Kraftstufe, welche vergleichbar ist mit einem Kletterer, der beidarmig die Säge bedient, wurden alle bis auf ein Seil durchtrennt. Die Ergebnisse werden im Zusammenhang mit Arbeitssicherheit diskutiert.

Resumen. Un estudio previo demostró la facilidad con la cual un(a) trepador(a) pudo cortar su cuerda usando un serrote manual (Kane et al. 2009). En un esfuerzo previamente publicado, sin embargo, los autores no examinaron el efecto de dos variables que presumiblemente influyen en la facilidad con la que una cuerda es cortada usando un tipo de hoja, con diferentes tensiones de la cuerda (siete niveles) y la fuerza de impacto (cuatro niveles) de la hoja montada en el péndulo sobre la cuerda. Los incrementos en la fuerza de impacto y la tensión de la cuerda aumentaron la facilidad de cortar ambas cuerdas probadas, pero la fuerza de impacto fue el efecto dominante. A mayor fuerza de impacto, la cual fue similar a la fuerza de impacto que un trepador pudo ejercer usando las dos manos en un serrote manual, una cuerda puede ser fue dañada completamente. Los resultados son discutidos en el contexto de la seguridad del trepador. 